\title{
A new species of Talavera Peckham et Peckham, 1909 (Aranei: Salticidae) from the Crimea
}

\author{
Новый вид рода Talavera Peckham et Peckham, 1909 \\ (Aranei: Salticidae) из Крыма
}

\author{
Mykola M. Kovblyuk, Zoya A. Kastrygina \\ Н.М. Ковбцюк, 3.А. Кастрыгина
}

V.I. Vernadsky Taurida National University, Yaltinskaya Street 4, Simferopol 295007, the Crimea. E-mail: kovblyuk@mail.ru;
zoiac_21@mail.ru
Таврический национальный университет им. В.И. Вернадского, ул. Ялтинская 4, Симферополь 295007, Крым.

KEY WORDS: spiders, Talavera, new species, description, the Crimea.

КЛЮЧЕВЫЕ СЛОВА: пауки, Talavera, новый вид, описание, Крым.

ABSTRACT. A new species, Talavera logunovi sp.n., from the Crimea is described and illustrated. The new species is the most similar to T. monticola. The males of T. logunovi sp.n. can be easily distinguished by the peculiar spine-shaped embolic tip (hook-like in T. monticola). The females of $T$. logunovi sp.n. differ from those of $T$. monticola in having the slightly longer insemination ducts.

РЕЗЮМЕ. Новый вид, Talavera logunovi sp.n., описан из Крыма. Новый вид наиболее близок к $T$. monticola. Самцы T. logunovi sp.n. хорошо отличаются характерным игловидным кончиком эмболюca (крючковидный у T. monticola). Самки T. logunovi sp.n. отличаются от $T$. monticola более длинными осеменительными каналами эпигины.

\section{Introduction}

The jumping spider genus Talavera has a Holarctic distribution [World Spider Catalog, 2015]. In total, fifteen species of Talavera are known. In North America, the only species known is the generotype: T. minuta (Banks, 1895) [World Spider Catalog, 2015]. Eleven species are known from Europe and thus Europe seems to be the diversity center of the genus.

Recently the genus was revised by Logunov \& Kronestedt [2003] and Wunderlich [2008], who provided the good identification keys for all the species described. However, some difficulties occur with the identification of Talavera species from the Karadag Nature Reserve in the Crimea. To date, we have accumulated many specimens (males and females) of this species in our collection. The goal of the present paper is to describe this obscure species as new.

\section{Material and methods}

The type specimens are shared between the National Arachnological Collection in V.I. Vernadsky Tauri- da National University, Simferopol, the Crimea, curator M.M. Kovblyuk (TNU), the Manchester Museum of the University of Manchester, UK, curator D.V. Logunov (MMUM), and the Zoological Museum of the Moscow State University, Moscow, Russia, curator K.G. Mikhailov (ZMMU).

Leg segments were measured after their separation from the prosoma. All measurements are in mm: minimum-maximum. Drawings were made using the dissecting and compound microscopes using a grid method. All scale bars are $0.1 \mathrm{~mm}$.

The format of description, morphological terminology and abbreviations follow Logunov \& Kronestedt [2003]: $C O$ - copulatory opening; $D S$ - distal sclerite of the tegulum; $E$ - embolus; $F D$ - fertilization duct; $I D$ - insemination duct; $M$ - exposed embolustegulum membrane; $R$ - receptacle.

\section{Taxonomy}

Genus Talavera Peckham et Peckham, 1909

Type species: T. minuta (Banks, 1895).

DIAGNOSIS. Talavera is closest to Euophrys C.L. Koch, 1834 sensu stricto, but can be easily distinguished by the absence of RTA (present in Euophrys), the male maxilla with the endite tooth (absent in Euophrys), the exposed embolus-tegulum membrane and the distal sclerite of the tegulum (both are unique diagnostic characters = apparently apomorphies) [Logunov, Kronestedt, 2003; Wunderlich, 2008].

DESCRIPTION. A detailed description of the genus was provided by Logunov \& Kronestedt [2003].

COMPOSITION. Currently genus encompasses 15 species [Logunov, Kronestedt, 2003; Wunderlich, 2008; World Spider Catalog, 2015].

DISTRIBUTION. Holarctic, with the majority of species occurring in Europe. 

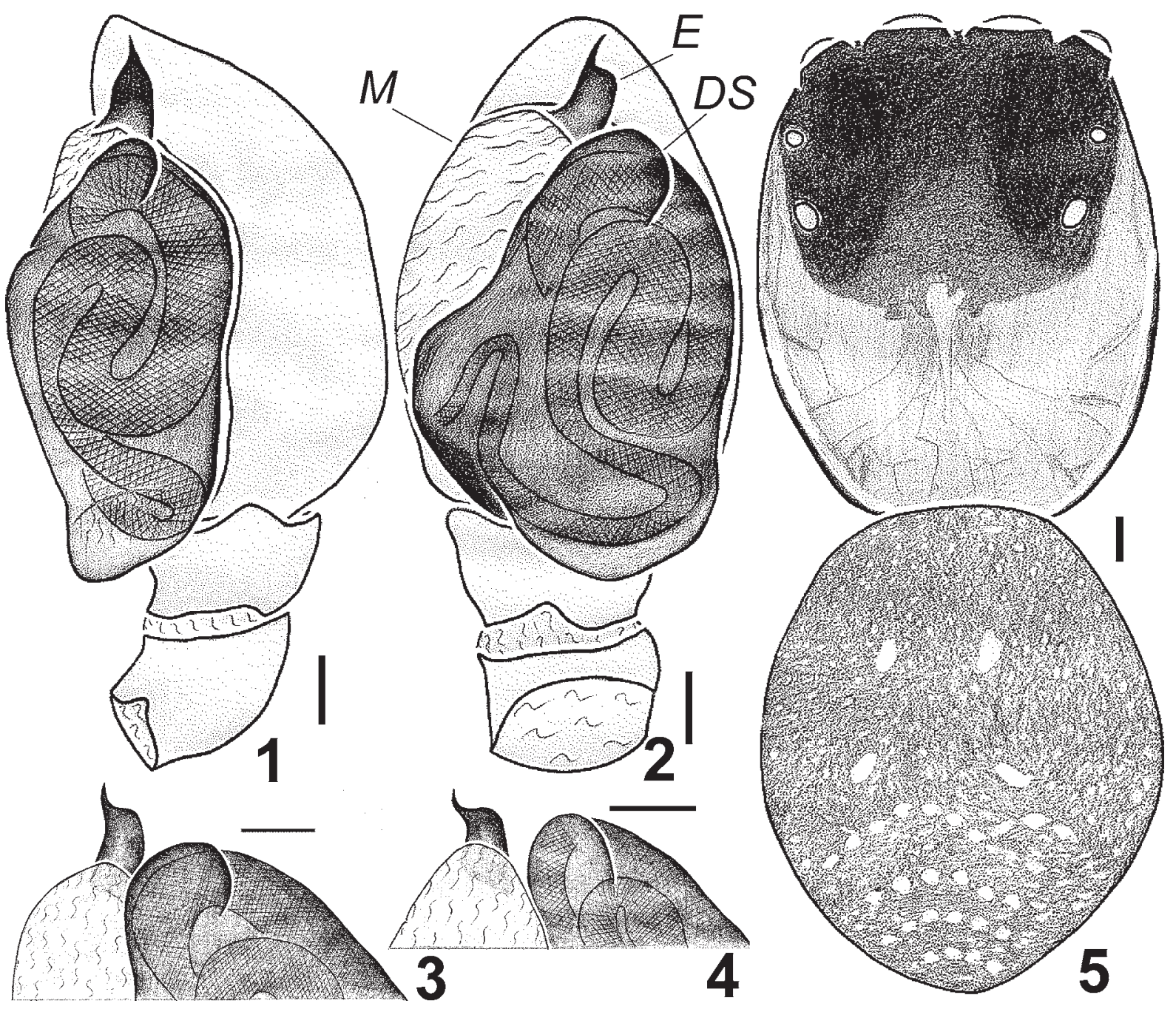

Figs 1-5. Male of Talavera logunovi sp.n.: 1 - palp, retrolateral view; 2 - palp, ventral view; $3-4$ - embolus, ventral view (variations); 5 - habitus, dorsal view. Abbreviations: $D S$ - distal sclerite of the tegulum; $E$ - embolus; $M$ - exposed embolus-tegulum membrane. Scale $0.1 \mathrm{~mm}$.

Рис. 1-5. Самец Talavera logunovi sp.n.: 1 - пальпа, ретролатерально; 2 - пальпа, вентрально; 3-4 - эмболюс, вентрально (вариации); 5 - габитус, дорсально. Обозначения: $D S$ - дистальный склерит тегулюма; $E$ - эмболюс; $M$ - наружная мембрана, соединяющая эмболюс с тегулюмом. Масштаб 0,1 мм.

\section{Talavera logunovi sp.n.}

Figs 1-9.

Talavera krocha Logunov et Kronestedt, 2003: 1106, figs 5961 ( $O^{\top}$ only).

MATERIAL. The Crimea. Feodosiya Distr., Karadag Nature Reserve: Holotype $\sigma^{7}$ (ZMMU from TNU-2595/9/1), Lobovoy Mt. Ridge, 28.05.2008, A.A. Nadolny. Paratypes: 1 O $^{2}$ (MMUM, vial No.1764/12 from TNU), the way from Biological station to GyaurCheshme spring and "Verhnie trassy" cordon, 17.05.2003, M.M Kovblyuk; 3 우 (TNU-2023/3/2), Besh-Tash valley, near the lake, wet meadow, 4.07.2004, M.M. Kovblyuk; 1 \% (TNU-1998/4), Besh-Tash valley, near the lake, Phragmites communis, Artemisia, Thymus, 9.07.2005, M.M. Kovblyuk; 1 क (TNU-2282/4), Karadag gulch, dry slope with Artemisia semidesert steppe, 9.07.2006, M.M. Kovblyuk; 1 (TNU-2397/5), the way from Biological station to spring Gyaur-Cheshme, Quercus pubescens forest, in litter, 3.07.2007, M.M. Kovblyuk; $1 \bigcirc^{7}, 1$ ( 1 (TNU-2595/9/2), Lobovoy Mt. Ridge, together with holotype, 28.05.2008, A.A. Nadolny; 1 O

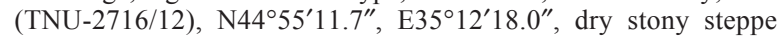

with lichen on the soil, 10 pitfall traps, 6-20.06.2008, A.A. Nadolny; 1 क (TNU-2722/11), same locality, 7 pitfall traps, 21.074.08.2008, A.A. Nadolny; $1 \sigma^{7}$ (TNU-2739/13), N44 55'10.9", E35 $12^{\prime} 17.6^{\prime \prime}, 37 \mathrm{~m}$, Quercus pubescens forest, 10 pitfall traps, 620.06.2008, A.A. Nadolny; 1 q (TNU-2936/9), N445 54'11.4", E35 $12^{\prime} 25.5^{\prime \prime}, 43 \mathrm{~m}$, ravine bottom, Quercus pubescens forest on the banks of the temporary stream, 9 pitfall traps, 15-29.08.2008, M.M. Kovblyuk; $1 \mathrm{O}^{7}$ (TNU-2870/12), N44 $54^{\prime} 58^{\prime \prime}$, E35 $12^{\circ} 21^{\prime \prime}$, $51 \mathrm{~m}$, Pistacia mutica forest in steppe, 11 pitfall traps, 6-20.06. 2008, A.A. Nadolny; 1 (TNU-2910/11), sea coast near of the mouth of the ravine "Chernyi Yar", N44'54'44.9", E35 $12^{\prime}$ '37.5", $5 \mathrm{~m}$, P. mutica and Cotinus coggygria on the crumbling seaside slope, 11 pitfall traps, 6-20.06.2008, M.M. Kovblyuk; $1 \mathrm{O}^{\mathrm{T}}$ (TNU-

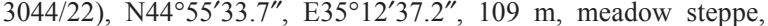
10 pitfall traps, 7-21.06.2008, M.M. Kovblyuk; 1 ㅇ (TNU-3045/ 14), same locality, 10 pitfall traps, 21.06.-3.07.2008, A.A. Nadolny; $2 O^{7} \sigma^{7}, 1$ ( (TNU-3046/17), same locality, 11 pitfall traps, 322.07.2008, A.A. Nadolny; 1 \% (TNU-3047/12), same locality, 10 pitfall traps, 22.07-5.08.2008, A.A. Nadolny; $1 \mathrm{O}^{\text {T }}$ (TNU-3188/

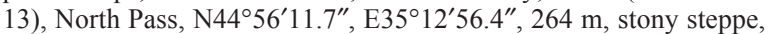
10 pitfall traps, 24.05-7.06.2008, M.M. Kovblyuk; 1 o (TNU- 
3189/11), same locality, 11 pitfall traps, 7-21.06.2008, A.A. Nadolny; 1 O, 1 (TNU-3191/11), same locality, 11 pitfall traps, $3-$ 22.07.2008, A.A. Nadolny; 1 क (TNU-2955/6), Beregovoy Mt

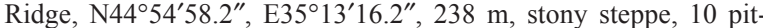
fall traps, 22.07-5.08.2008, A.A. Nadolny; 1 ㅇ (TNU-2973/19), Beregovoy Mt. ridge, N4454'57.6", E35 13'05.0”, 226 m, Juniperus excelsa forest, 10 pitfall traps, 7-21.06.2008, M.M. Kovblyuk; 1 (TNU-2975/20), same locality, 10 pitfall traps, 3-22.07.2008, A.A. Nadolny; 1 O (TNU-3259/90), sifting, 28-31.05.2010, M.M Kovblyuk, N.N. Yunakov; $1 \sigma^{7}$ (TNU-3157/17), Biological station, 15.05-06.2012, O.V. Kukushkin; 1 ㅇ (TNU-3320/13), Biological station, 24.05-14.06.2013, O.V. Kukushkin.

COMMENTS. The male of this new species was described and illustrated by Logunov \& Kronestedt [2003] from the Chernomorskii Steppe Reserve (Kherson Area of Ukraine) under the name of Talavera krocha Logunov et Kronestedt, 2003. The figures and description of male well correspond to those of the males in our material from the Crimea. The female of T. krocha illustrated by Logunov \& Kronestedt [2003: figs 62-64] on the basis of the paratype from France is very different from the Crimean females. According to Logunov \& Kronestedt [2003: 1107], "the male is provisionally matched with the female, as ... no samples in which both sex were collected together".

The male described under the name of T. krocha is most similar to that of T. monticola (Kulczyński, 1884), but the females are similar to those of T. aperta (Miller, 1971) [Logunov, Kronestedt 2003: 1106-1107]. In our material some males and females were collected together (see above under the 'Material') and both sexes are most similar to those of T. monticola.

Based on the structure of copulatory organs, the genus Talavera was divided into three species groups, two of which were further divided into subgroups [Logunov, Kronestedt 2003]. The monticola group was subdivided into two subgroups: the thorelli and monticola subgroups. In thorelli subgroup the epigynal plate always forms a central atrium, and the epigynal fold is present. In monticola subgroup the epigyne is without a central atrium, and the epigynal fold is poorly marked, almost invisible. The females described by Logunov \& Kronestedt [2003] under the name of T. krocha belong to thorelli subgroup, but the male is closely related to T. monticola from the monticola subgroup. Therefore, it is safe to conclude that Logunov \& Kronestedt [2003] mismatched the male and the female of Talavera krocha Logunov et Kronestedt, 2003. The female holotype of T. krocha originated from Kirovograd Area of Ukraine, whereas the male paratype of T. krocha originated from the Chernomorskii Steppe Reserve. To conclude, the male described by Logunov \& Kronestedt [2003] under the name of T. krocha and our Talavera specimens from the Karadag Nature Reserve belong to the same and undescribed species. This species is diagnosed and described in the present paper.

DIAGNOSIS. The new species belongs to the monticola group and monticola subgroup [sensu Logunov \& Kronestedt, 2003]. Both sexes of T. logunovi sp.n. are most similar to those of $T$. monticola from the mountains of Central Europe (the Alps, Tatras, the Carpathians). The male of $T$. logunovi sp.n. can be easily distinguished by the peculiar spine-shaped embolic tip (hook-like in $T$. monticola). The female of $T$. logunovi sp.n. differs from T. monticola in having the slightly longer insemination ducts. The latter character is a poor diagnostic character, but yet the females in the monticola subgroup were reported to be indistinguishable [Logunov, Kronestedt, 2003: 1112]. Some females of $T$. monticola have the entrances of the insemination ducts clearly directed towards each other [Logunov, Kronestedt, 2003: p. 1123], while we have found no specimen with such trajectory of the insemination ducts in the studied material of the new species.

DESCRIPTION. Male (paratype, TNU-3044/22). Measurements. Total length 2.2. Carapace 1.15 long, 0.85 wide, 0.48 high at PLE. Ocular area 0.43 long, 0.69 wide anteriorly and 0.66 wide posteriorly. Diameter of AME 0.20. Abdomen 1.12 long, 0.78 wide. Cheliceral length 0.29 . Clypeal height 0.04 . Length of leg segments:

\begin{tabular}{|l|l|l|l|l|l|l|}
\hline & $\mathrm{Fm}$ & $\mathrm{Pt}$ & $\mathrm{Tb}$ & $\mathrm{Mt}$ & $\mathrm{Tr}$ & Total \\
\hline I & 0.53 & 0.29 & 0.32 & 0.31 & 0.25 & 1.71 \\
\hline II & 0.48 & 0.31 & 0.28 & 0.27 & 0.20 & 1.53 \\
\hline III & 0.67 & 0.31 & 0.36 & 0.36 & 0.27 & 1.97 \\
\hline IV & 0.62 & 0.28 & 0.41 & 0.38 & 0.32 & 2.00 \\
\hline
\end{tabular}

Leg spination. Leg I: Fm d 1-1-1; Tb v 1-2-2ap; Mt v 2-2ap. Leg II: Fm d 1-1-2; Tb pr 1, v 1-2-2ap; Mt pr and rt 1, v 2-2ap. Leg III: Fm d 1-1-1, pr 1-1; Tb pr and rt 1-1, v 1-2; Mt pr, rt and v 1-2ap. Leg IV: Fm d 1-1-12; Tb pr and v 1-1; Mt pr and rt 1-1, v 1-2ap.

Coloration. Carapace brown, with black eye field and light spots on its sides at the rear part of eye field. Thoracic part of carapace with black margins and a light marginal line. Black field around eyes. Carapace is covered with elongated white scales. AMEs with a greenish sheen, surrounded by white (above) and red (below) cilia. Clypeus covered with red scales/hairs. Chelicerae, labium, sternum, maxillae light-brown. Abdomen: dorsum brown, with yellow reticulate colour pattern; venter brown, with two light stripes from epigastric furrow to scutum, situated in front of spinnerets. Length of ventral scutum is equal to $1 / 4$ of the distance from the tracheal spiracle to the epigastral furrow. Scutal width three times greater than its length. Book-lung covers light. Spinnerets brown. Leg I from femur to middle metatarsus dark (black); distal half of metatarsus and tarsus light. Leg II: femur dark, remaining segments light, with black rings. Leg III: femur dark, remaining segments light. Leg IV: all segments light with black rings. Palps light, only cymbial tip and tegulum dark brown. Cymbium with dense, basal-prolateral bunch of long white hairs.

Palpal structure as in Figs 1-4.

Female (paratype, TNU-2975/20; all other $q$ paratypes have been measured in order to assess a variation of the carapace size). Measurements. Total length 1.98-3.08, carapace 1.02-1.30 long, 0.75-0.95 wide $(n=16)$. High of carapace at PLE 0.50 . Ocular area 0.45 long, 0.70 wide anteriorly and 0.62 wide posteriorly. Diameter of AME 0.2. Abdomen 1.55 long, 

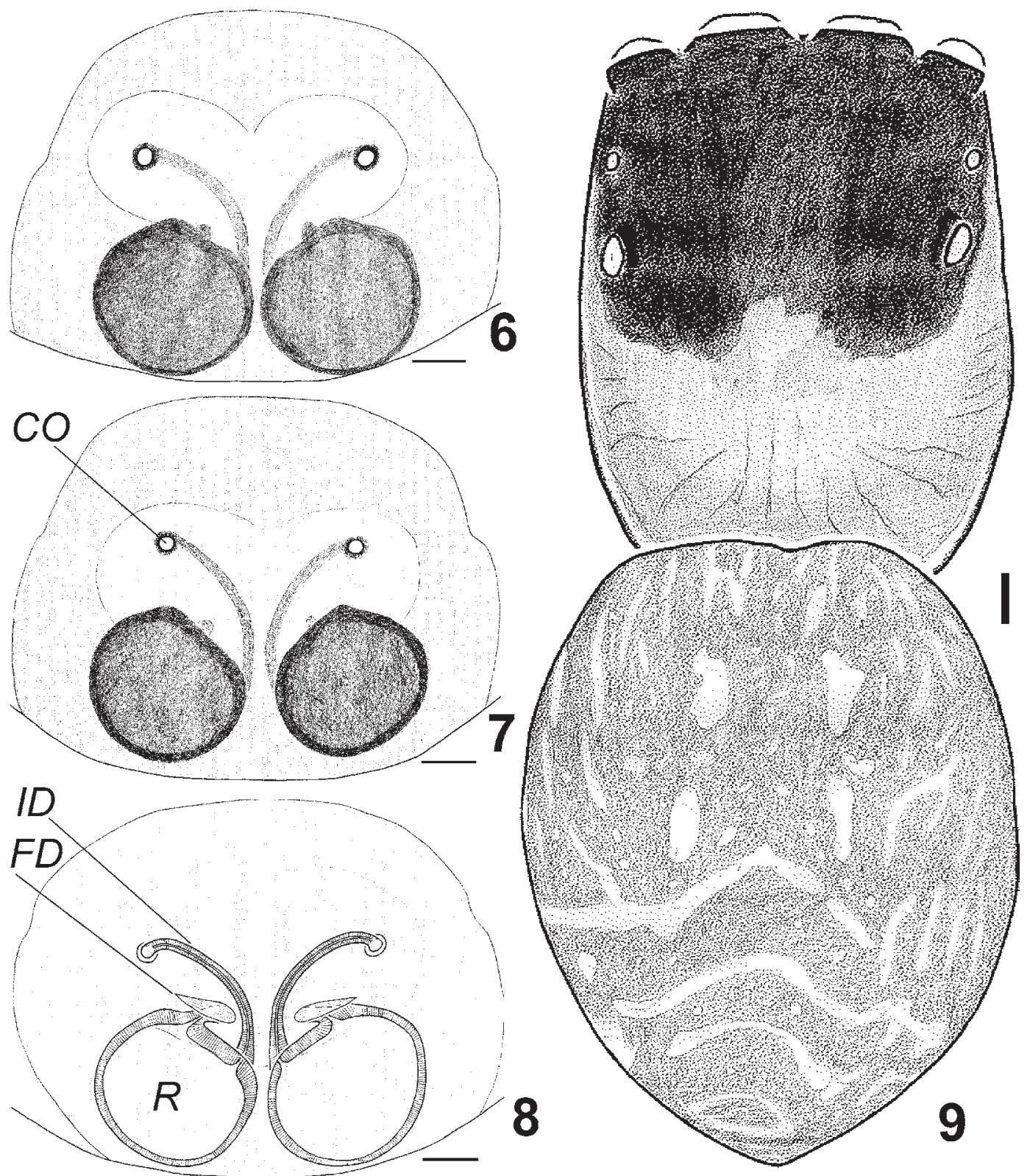

Figs 6-9. Female of Talavera logunovi sp.n.: 6-7 - epigyne, ventral view (variations); 8 - epigyne, dorsal view; 9 - habitus, dorsal view. Abbreviations: $C O$ - copulatory opening; $F D$ - fertilization duct; $I D$ - insemination duct; $R$ - receptacle. Scale $0.1 \mathrm{~mm}$.

Рис. 6-9. Самка Talavera logunovi sp.n.: 6-7 - эпигина, вентрально (вариации); 8 - эпигина, дорсально; 9 - габитус, дорсально. Обозначения: $C O$ - копуляторное отверстие; $F D$ - оплодотворительные каналы; $I D$ - осеменительные каналы; $R$ резервуар. Масштаб 0,1 мм.

1.15 wide. Cheliceral length 0.28 . Clypeal height 0.10 . Length of leg segments:

\begin{tabular}{|l|l|l|l|l|l|l|}
\hline & $\mathrm{Fm}$ & $\mathrm{Pt}$ & $\mathrm{Tb}$ & $\mathrm{M} \mathrm{t}$ & $\mathrm{Tr}$ & Total \\
\hline I & 0.49 & 0.29 & 0.28 & 0.25 & 0.20 & 1.51 \\
\hline II & 0.43 & 0.27 & 0.24 & 0.22 & 0.18 & 1.34 \\
\hline III & 0.59 & 0.31 & 0.32 & 0.29 & 0.24 & 1.75 \\
\hline IV & 0.59 & 0.28 & 0.39 & 0.36 & 0.29 & 1.92 \\
\hline
\end{tabular}

Leg spination. Leg I: Fm d 2; Tb v 2-2-2; Mt v 2-2. Leg II: Fm d 1-1-1; Tb v 1-1; Mt v 2-2. Leg III: Fm d 1; Tb pr, rt and v 1-1; Mt pr, rt and v 1-2. Leg IV: Fm d 1$1-1 ; \mathrm{Tb}$ pr, rt and v 1; Mt pr and rt 1-2, v 1.
Coloration. Carapace brown, with black eye field and light spots on its sides at the rear part of eye field. Thoracic part of carapace with black margins and a light marginal line. Black around eyes. Carapace is covered with elongated white scales/hairs. AMEs with a greenish sheen, surrounded by white cilia. Clypeus is covered with white scales/hairs. Chelicerae, labium, sternum, maxillae light brown. Abdomen: dorsum brown, with yellow reticulate colour pattern; venter brown, with two light stripes from the epigastral furrow to spinnerets. Book-lung covers light. Spinnerets brown. Leg I: femur dark on its sides; patella darkened distal- 
ly; tibia with two spots from the sides distally; metatarsus slightly darkened proximally; tarsus light. Leg II: femur discontinuously darkened on its prolateral side; patella darkened distally; tibia with two spots from the sides distally; metatarsus more darkened than metatarsus of the leg I; tarsus darkened proximally. Legs IIIIV: all segments light yellow, with black rings. Palps light yellow.

Epigyne and spermathecae as in Figs 6-8.

TYPE LOCALITY. The Crimea, Karadag Nature Reserve.

DISTRIBUTION. Ukraine (Kherson Area and the Crimea).

HABITATS. The sub-Mediterranean forests with Quercus pubescens, Pistacia mutica and Juniperus excelsa; meadows; meadow steppes; stony steppes; Artemisia semidesert steppes.

PHENOLOGY. O'T - V-VII, $90-$ VIII, the peak activity of adults occurs in July.

ETYMOLOGY. The species is named in honour of Dmitri Viktorovich Logunov (Manchester, UK), the arachnologist who has published many papers devoted Salticidae.

ACKNOWLEDGEMENTS. We are very grateful to O.V. Kukushkin (Karadag Nature Reserve, the Crimea), A.A. Nadolny (Simferopol) and N.N. Yunakov (Magdeburg, Germany) who provided us with the material used in this study. We thank P.E. Gol'din (Kiev) for improving the English of the earlier draft. Special thanks go to D.V. Logunov (Manchester, UK) who edited its final version. This work was supported in part by the Karadag Nature Reserve.

\section{References}

Logunov D.V., Kronestedt T. 2003. A review of the genus Talavera Peckham and Peckham, 1909 (Arareae, Salticidae) // Journal of Natural History. Vol.37. P.1091-1154.

World Spider Catalog. 2015. Natural History Museum Bern, online at: http:wsc.nmbe.ch, version 15.5 (accessed on 2.01.2015).

Wunderlich J. 2008. On the identification and taxonomy of the central European jumping spiders (Araneae: Salticidae) of the tribus Euophrydini, with special reference to Talavera // Beiträge zur Araneologie. Bd.5. P.720-735.

Responsible editor K.G. Mikhailov 